\title{
Light trap studies of Heliothis virescens (Fabricius) and Etiella zinckenella (Treitschke) in pigeon pea (Cajanus cajan Millsp.) fields'
}

\author{
Aristides M. Armstrong 2
}

\begin{abstract}
Light trap studies on population abundance of Heliothis virescens and Etiella zinckenella on different stages (bloom and pod formation) of pigeon pea were conducted during the growing seasons of 1984,1985 and 1986 . Cultivars Kaki and 2B-Bushy were used. Heliofhis virescens was more abundant than E. zinckenella. Both species were detected at the bloom stage, but $H$, virescens predominated at the bloom and pod formation stage, indicating an early infestation. At the dry pod stage, adults of $E$. zinckenello were noticeable when the pods approached maturity (full pod stage) reaching a peak number during the dry pod stage. Both pod borers were more abundant at the harvest period (green pods). It is suggested that overlapping generations of both species and their life cycles are synchronous with the phenology of the crop.
\end{abstract}

\section{RESUMEN}

\section{Heliothis virescens y Etiella zinckenella capturados en trampas lumínicas en gandulares}

En 1984, 1985 y 1986 se hicieron estudios con trampas lumínicas para establecer preliminarmente si había Heliothis virescens y Efiella zinckenella en las diferentes etapas de desarrollo del gandul (floración y formación de la vaina). Se sembraron las variedades Kaki y 2B-Bushy. Los resultados indican que $H$. virescens es más predominante que $E$. zinckenella. Aunque ambas especies se detectaron en la etapa de florecida, $H$. virescens se capturó en mayor número durante las etapas de floración y formación de la vaina. Los adulıs de E. zinckenella se capłuraron en mayor número cuando las vainas estaban ya maduras alcanzando su número máximo durante la etapa de vainas secas. Ambas especies de barrenadores se capturaron en gran número durante la época de cosecha (vainas verdes). Se sugiere una posible sobreposición de generaciones de ambas especies coincidiendo con una mayor abundancia en la cosecha y una sineronía de los ciclos de vida de estos insectos con la fenología del cultivo.

\section{INTRODUCTION}

Pigeon pea is the main legume crop in the hills and on the southern coast of Puerto Rico. The crop is attacked by various insects, especially the pod borers. The larvae of Heliothis virescens (Fabricius) (Lepidop-

'Manuscript submitted to Editorial Board 29 March 1988.

${ }^{2}$ Research Assistant in Entomology, Department of Crop Protection, Agricultural Experiment Station, University of Puerto Rico, Mayagüez Campus. 
tera: Noctuidae) and Etiella zinckenella (Treitschke) (Lepidoptera: Pyralidae) bore pods, reducing quality and yield because of the partial or entire destruction of the peas. Economic losses may also oceur because of the partial or entire destruction of the peas. Economic losses may also occur because of the dropping of buds, flowers and pods $(1,11,13)$.

Light traps have been used for many years to attract and capture insects for the detection, analysis, and forecasting of outbreaks of insect pests (9). They have also been used to estimate seasonal changes in insect abundance (4). The size of the nightly cateh is determined in part by the number of insects available, by the environmental factors that affect insect activity (moonlight, temperature, wind speed, clouds, ete.) (13), insect behavior (2), and by the trap design (11). According to Southwood (11), any sampling procedure that estimates only part of the actual insect population in a given area is referred to as a relative estimate. Therefore, preliminary exploratory tests were conducted to obtain a relative estimate of the composition of adult pod borer species at various stages of pod development.

\section{MATERIALS AND METHODS}

For each growing season (1983-84, 1984-85 and 1985-86), a small plot of pigeon pea was established except for 1985-86, when two plots of different cultivars were sown for a total of four trials for the whole study. This study was condueted at the Isabela Research and Development Center and the cultivars used were Kaki and 2B-Bushy (tables 1 and 2). Each plot was $25 \mathrm{~m} \times 16.7 \mathrm{~m}\left(417.5 \mathrm{~m}^{2}\right)$ with about 425 plants per plot. For the first trials, cv. Kaki was used and sown early in the season (July-August), and in the last trial, cv. 2R-Bushy was sown late in the season (September).

A survey blacklight trap (the Pennsylvanian trap-type) (11) $1.5 \mathrm{~m}$ high, with a circular roof to prevent the entry of rain into the killing bottle and a 15-watt central tube surrounded by four baffles was placed over a $1.33 \mathrm{~m}$ high wooden table, so that the light source was at a higher altitude than the plants. The light trap was set at the first indication of blooming and was lighted once a week during pod formation up to 4 weeks after harvesting. Insects were collected in a glass jar provided with a killing agent and brought to the laboratory for identification. An adaptation of the classification of soybean developmental stages (3) was used in this study to describe similar stages in the pigeon pea plant.

\section{RESULTS}

\section{Heliothis virescens}

The results obtained for the 1983-84 season (table 1) show that adults of Heliothis virescens occurred in large numbers during the bloom stage. The largest number was collected during the fullpod stage. Afterwards, 
TABLE 1.-Percent of total catch of Heliothis virescens based on a weekly catch with a light trap during three consecutive grouning seasons (July-April) of pigeon pea at Isabela, $P$. R.

\begin{tabular}{|c|c|c|c|c|c|c|c|c|c|c|c|c|}
\hline \multirow[b]{2}{*}{ Stage of the crop } & \multicolumn{3}{|c|}{$1983-84^{1}$} & \multicolumn{3}{|c|}{$1984-85^{2}$} & \multicolumn{3}{|c|}{$1985-86^{3}$} & \multicolumn{3}{|c|}{$1985-86^{4}$} \\
\hline & No. & $\%$ & Totaig & No. & $\%$ & Totals & No. & $\%$ & Total $^{5}$ & No. & $\%$ & Totalt \\
\hline Full bloom stage & 57 & 55 & 104 & 22 & 17 & 128 & 22 & 40 & 55 & 26 & 51 & 52 \\
\hline Beginning pod stage & 91 & 64 & 143 & 18 & 19 & 95 & 20 & 19 & 108 & 11 & 36 & 31 \\
\hline Full pod stage & 137 & 61 & 224 & 60 & 50 & 121 & 28 & 19 & 146 & 12 & 26 & 47 \\
\hline
\end{tabular}

Established in August 1988 - cv. Kaki.

" " July 1984 - cv. Kaki.

3 " "August 1985 - cv. Kaki.

4 " "September 1985 - cv, 2B-Bushy.

${ }^{5}$ Total number of lepidoptera captured per catch per week. 
in the dry pod stage, the number of adults captured decreased. Heliothis virescens represented $48 \%$ of the total catch of insects collected.

For the 1984-85 season (table 1) adults were first collected early in the beginning bloom stage. The largest number of adult insects was collected during the full pod stage. Numbers of $H$. virescens collected during the season represented $25 \%$ of the total catch.

The numbers of adults trapped for the 1985-86 season (with cv. Kaki) were constant through the season (table 1), with a tendency to be higher in the bloom stage. For this trial, adults collected represented $24 \%$ of the total catch. For the plot sown late in the season of 1985-86 (cv. 2B-Bushy) the number of adults trapped varied through the season with the largest number captured early in the bloom stage. Even though the total catch $H$, virescens during the season represented $38 \%$ of the total catch, the insect catch for $H$. virescens collected contained the least number of adults. As in the other trials, there was a tendency to a decrease in number of adults per catch during the dry pod stage.

\section{Etiella zinckenella}

For the 1983-84 season and 1984-85 season, no adults of Etiella zinckenella were collected during the bloom stages (table 2). For both seasons, adults were first collected during pod formation and most adults during the last stages of the crop-the dry pod stage. Captured insects of this species represented $22 \%$ and $12 \%$ of the total catch for each season, respectively.

For the 1985-86 season, (cv. Kaki, sown early in the season and cv. 2B-Bushy, sown late in the season), adults of E. zinckenella were collected at the beginning bloom stage. With the cv. Kaki (sown early in the season) more insects were captured as the pods were maturing (table 2), with greater abundance during the dry pod stage close to the end of the season. For the crop sown late in the season, cv. 2B-Bushy, the number of adults of $E$. zinckenella captured was low through the season. For both trials, insects collected represented for each season, respectively, $30 \%$ and $19 \%$ of the total catch.

\section{DISCUSSION}

The author realizes that the estimation of absolute population by relative methods, i.e. light trap, is difficult. What one really estimates is the proportion of the population that was in the "phase" to respond to the trap (11). Notwithstanding the limitations of the light trap, this tool is very helpful for obtaining an idea of the number of insects present at a determined moment. In our studies we found Heliothis virescens as the dominant species affecting the pods. This finding corroborates studies by Cruz (1). A large number of adults captured at the beginning of the bloom stage suggests that a large number of eggs will be deposited in 
TABLE 2.-Percent of total catch of Etiella zinckenella based on a weekly catch with a light trap during three consecutive growing seasons (July-April) of pigeon pea at Isabela, P. R.

\begin{tabular}{|c|c|c|c|c|c|c|c|c|c|c|c|c|}
\hline Stage of the crop & \multicolumn{3}{|c|}{$1983-84^{1}$} & \multicolumn{3}{|c|}{$198485^{*}$} & \multicolumn{3}{|c|}{$1985-86^{3}$} & \multicolumn{3}{|c|}{$1985-86^{4}$} \\
\hline Full bloom stage & - & - & 104 & - & - & 128 & 5 & 9 & 55 & 8 & 18 & 51 \\
\hline Beginning pod stage & 15 & 11 & 143 & 10 & 11 & 95 & 41 & 38 & 108 & 7 & 23 & 31 \\
\hline Full pod stage & 30 & 13 & 224 & 28 & 23 & 121 & 58 & 40 & 146 & 13 & 28 & 47 \\
\hline Dry pod stage & 113 & 50 & 228 & 15 & 38 & 42 & 62 & 61 & 101 & 11 & 14 & 40 \\
\hline
\end{tabular}

'Established in August 1983 - cv. Kaki.

" July 1984 - cv. Kaki.

" August 1985 - ev. Kaki.

" September 1985 - cv, 2B-Bushy.

sTotal number of lepidoptera captured per catch per week 
that period. Studies by Cruz (1) indicate that infestation of the pod borer at this stage will reduce the yield considerably. Other studies by McWilliams (8) on soybean indicate that infestations by $H$. virescens as early as the R2 stage (full bloom stage) will reduce the yield. Authors agree that the greatest damage is caused by the 3rd and 4th instars of the larvae at the beginning of the pod stage (7). Since the number of adults captured increases parallel to pod formation, it is assumed that a great oviposition activity and overlapping generations will continuously infest the crop. As soon as no flowers are present and green pods become scarce, fewer adults are captured; thus there is a synchrony of $H$. virescens and pigeon pea development.

In the case of Etiella zinckenella, although on two occasions at different times of the seasons (table 2), adults were captured at the beginning of the bloom stage, the greatest number of adults was found when the pod was fully developed. Given a great oviposition activity at this time, an infestation at that stage will reduce considerably the yield of green pods or dry pods. Studies by Hattori and Sato (5) corroborate my preliminary findings in that this insect is more abundant between November and February, indicating the insect preference for cooler and drier weather. Other studies by Lobo and Viereck (6) sustain the findings that $E$. zinckenella attacks the well developed pods of Cajanus cajan whereas Heliothis spp. attack the new pods and flowers.

In a program of control of pod borers in pigeon peas in Puerto Rico we should consider both speeies, Heliothis virescens and Etiella zinckenella, because they can coincide with the bloom stage and cause a heavy infestation. But as this study indicates, $H$. virescens is more common in the bloom stage, establishing early infestations and causing severe damage to the pods, buds and flowers. When the pods are full and mature, E. zinckenella is more abundant, causing more damage at that stage. Various generations of both species may coincide and overlap in the full pod stage and dry pod stage. Our previous experience indicates that during the harvest most larvae present are the mature larvae of both species. In Puerto Rico, pigeon pea is usually harvested when the pod is mature and green (full pod stage). Therefore, to obtain good control of these insects, we have to consider that probably the time of attack will be different for each species, but the infestation (greatest damage) may coincide. Any method of control will have to start at the beginning bloom stage and continue through the harvest.

\section{LITERATURE CITED}

1. Cruz, C., 1975, Observations on pod borex oviposition and infestation of pigeon pea varieties. J. Agric. Univ. P. R. 59 (1):63-8. 
2. Douthwaite, R. J., 1978. Some effects of weather and moonlight on light trap catches of the armyworm, Spodoptera exempta (Walker) (Lepidoptera:Noctuidae), at Mugua, Kenya. Bull. Entomol. Res. 68:533-42.

3. Fehr, V. R. and C. E. Caviness, 1977. Stages of soybean development. Iowa State Univ. Speeial Rep. 80.

4. Harstack, A. W. Jr., J. P. Holligsworth, R. L. Ridgway and J. R. Coppedge, 1973. A population dynamies study of the bollworm and the tobacco budworm with light traps, Environ. Entomol. 2:244-52.

5. Hattori, M. and A. Sato, 1983. Substrate factors involved in oviposition response of the lima bean pod borer, Etiella zinckenella Treitshke (Lepidoptera: Pyralidae). Appl. Ent. Zool. 18 (1):50-6.

6. Lobo, M.L. and A. Viereck, 1986. Entomological problems of the main crops in Cape Verde. In Proc. of an International Seminar of the CILSS Project on Integrated Pest Management, Niamey (Niger) 6-13 Dec. 1984. pp. 55-6.

7. MeWilliams, J., 1983. Relationship of soybean pod development to bollworm and tobacco budworm damage. J. Econ. Entomol. 76 (3):502-06.

8. McWilliams, J. M., 1984. Effects of tobaceo budworm (Lepidoptera:Noctuidae) infestations on pod damage and yield loss in soybean. J. Econ. Entomol. 77 (2):364-69.

9. Morton, R., L. D. Tuart and K. G. Wardhaugh, 1981, The analysis and standardisation of light-trap catches of Heliothis armigera (Hubner) and $H$. punctiger Wallengren (Lepidoptera:Noctuidae). Bull. Ent. Res. 71:207-25.

10. Seott, L. B., 1940. The lima bean pod borers in Puerto Rieo, J. Agric. Univ. P. R. $24(2): 35-47$.

11. Southwood, T. R. E., 1978. Ecological Methods, 2nd ed., Chapman and Hall, New York.

12. Talekar, N. S. and Bor Shyan Chen, 1983. Seasonality of insect pests of soybean and mungbeans in Taiwan. J. Econ. Entomol. 76 (1):34-7.

13. Williams, C. B., 1940. An analysis of four years captures of inseet in a light trap. Part II. The effect of weather conditions on insect activity; and the estimation of forecasting of changes in the insect population. Trans. $R$. Ent. Soc. Lond. 90:227-306.

14. Wolcott, G. N., 1933. Lima bean pod borer caterpillars of Puerto Rico. J. Agric. Univ. P. R. $17(3): 241-55$. 
